This PDF is a selection from an out-of-print volume from the National Bureau of Economic Research

Volume Title: The Rate and Direction of Inventive Activity: Economic and Social Factors

Volume Author/Editor: Universities-National Bureau Committee for Economic Research, Committee on Economic Growth of the Social Science Research Council

Volume Publisher: Princeton University Press

Volume ISBN: 0-87014-304-2

Volume URL: http://www.nber.org/books/univ62-1

Publication Date: 1962

Chapter Title: Invention and Innovation in the Petroleum Refining Industry

Chapter Author: John L. Enos

Chapter URL: http://www.nber.org/chapters/c2124

Chapter pages in book: (p. 299 - 322) 


\title{
Invention and Innovation in the Petroleum Refining Industry
}

\author{
JOHN L. ENOS \\ MASSACHUSETTS INSTITUTE OF TECHNOLOGY
}

AN INNOVATION is the combination of many different activities. Generally an invention is made and recognized, capital is obtained, plant is acquired, managers and workers are hired, markets are developed, and production and distribution take place. As the innovation proceeds the original conception may be altered to make it more amenable to commercial realities. Accomplishing these activities consumes resources. At any point in the sequence failure may occur, delaying or even frustrating the innovation.

In studying the petroleum refining industry I observed several processing innovations following one another in time and generating technological progress. ${ }^{1}$ I then sought their origins in terms of the original ideas and the men who conceived them. In this paper I shall discuss the relations between the inventions and the subsequent innovations, focusing on the intervals between them, the returns to the inventors and innovators, and the changes in the proportions in which the factors of production in petroleum processing were combined.

\section{Invention and Innovation in the Cracking of Petroleum}

As it comes from the earth, crude petroleum is a varying mixture of hydrocarbons of different molecular weights. In addition to separating the hydrocarbons physically according to their properties-boiling range, combustion characteristics, etc.-refiners have found it profitable to process certain of the hydrocarbons chemically. Most of their efforts have been directed at altering the heavier and lower-priced components. Most significant have been those processes designed to derive motor gasoline from the heavy hydrocarbons. Those processes involve the chemical process of cracking, or the splitting of large hydrocarbon molecules into smaller ones. When produced under the

NoTE: The author wishes to thank Zvi Griliches for his comments on the original draft.

${ }^{1}$ These innovations are described in the author's Ph.D. thesis, "History of Cracking in the Petroleum Refining Industry: the Economics of a Changing Technology," Massachusetts Institute of Technology, June 1958. The major portion of the thesis is to be published as Technological Progress in Petroleum Refining (Cambridge, The Technology Press, 1961). 
proper conditions, the cracked molecules are an excellent fuel in internal combustion engines.

The first commercially successful process to crack heavy hydrocarbons into motor gasoline components was introduced in 1913. Since then there have been eight more process innovations, comprising three waves, one in the early 1920's, another in 1936, and the final one in the 1940's. Each successive wave has yielded improved processes, which have generally displaced those from an earlier wave.

For each of these successful innovations, I attempted to select the one or possibly two inventions which first revealed the general ideas. It is always difficult, if not impossible, to follow an innovation back to a single source. Sometimes an innovation will include several new elements, each of which required an invention. Sometimes it is possible to find the germs of an invention in still an earlier work. The selection, therefore, is quite arbitrary, and the accuracy of the data questionable.

Cracking is almost as old as the oil industry. The phenomenon had been noticed in the 1850 's and utilized from 1860 on in the manufacture of kerosene. In cracking to yield kerosene, the process was carried on at atmospheric pressure. In 1889, however, a patent was obtained by two English chemists, J. Dewar and B. Redwood, on cracking and condensing under pressure. ${ }^{2}$ When pressure was used, the product was found to boil in the gasoline rather than the kerosene range. W. M. Burton, a refinery manager for the Standard Oil Company (Indiana), added to this and other earlier ideas the specification that a relatively narrow hydrocarbon fraction, commonly called gas-oil, be cracked, rather than the entire portion of crude oil boiling above kerosene. Gas-oil is that fraction of crude petroleum lying in the boiling range between kerosene and heavy fuel oil. Depending upon the type of crude petroleum, gas-oil will account for 30 to 50 per cent of its total volume. This specification, plus the design of the physical apparatus required to carry out the cracking process, was stated by Burton and his assistant, R. M. Humphreys, around 1910. In 1913 the Burton process was first applied by Indiana Standard and operated by them and later by others most profitably for about a decade.

Burton's process was limited in that it could not be operated continuously; the cracking retort had to be shut down every day or so to be cleaned out. Besides the technical limitations, the process was well

\footnotetext{
${ }^{2}$ For a description of Dewar and Redwood's and other early cracking processes, see Carleton Ellis, Gasoline and Other Motor Fuels, New York, Van Nostrand, 1921. The early work is summarized in Kendall Beaton, Enterprise in Oil, New York, AppletonCentury-Crofts, 1957, pp. 345-46.
} 
supported by patents and the right to utilize it was not widely granted. As a result, attention was given to developing a continuous thermal cracking process. Within a few years of 1920 four major and several minor continuous thermal cracking processes were introduced.

One of the major processes was the Holmes-Manley process, based upon the invention of Joseph H. Adams, an independent inventor, who in about 1909 conceived of a continuous cracking operation. His ideas underlay a commercial process, the development of which was carried out by R. C. Holmes and F. T. Manley, two refining executives of the Texas Company. ${ }^{3}$ The Holmes-Manley process (it took its name from the innovators rather than the inventor) was installed commercially in 1920 .

The second of the major processes was named after its inventors, Jesse A. and Carbon P. Dubbs. The former, like Adams, conceived of the idea of a continuous process, the latter of a recirculation of the hot uncracked material so as to increase the yield of gasoline. These inventions were made in 1909 and 1919, respectively; the first commercial application occurred in $1922 .{ }^{4}$ The Dubbs process was promoted by a new process design firm, Universal Oil Products Company.

The third major process, the Tube and Tank, was the product of Esso Research and Engineering Company, then the Development Department of the Standard Oil Company (New Jersey). Again it was the concept of a continuous thermal cracking process that underlay the innovation; in this instance it was also an independent inventor, one who specialized in petroleum chemistry, Carleton Ellis, who conceived of the idea and made patent applications in 1909. The patents were subsequently purchased by Jersey in order to give protection to a process already well advanced in its development.

The final important continuous thermal cracking process was the Cross, invented and developed by Walter and Roy Cross, chemists who worked first with pharmaceuticals and later with petroleum. As in the case of the Dubbs process, a process licensing firm, Gasoline Products Company, was established to promote Cross's design. Unlike Universal Oil Products, this firm lasted no longer than the Cross process itself, becoming insignificant in the 1940's.

\footnotetext{
${ }^{3}$ The Holmes-Manley and the other continuous thermal processes are best described in E. H. Leslie, Motor Fuels, New York, Chemical Catalog Co., 1923. For a discussion of the cracking patents and the litigation that arose over them, see G. S. Gibb and E. H. Knowlton, History of the Standard Oil Company (New Jersey), 1911-1927, The Resurgent Years, New York: Harper, 1956, pp. 547-559.

4 The Dubbs process is described in Beaton, op. cit., pp. 241-246.
} 
The four inventions, by Adams, Dubbs, Ellis, and Cross, are quite similar in nature. Each advanced the idea of continuous processing, although each called for different apparatus and operating conditions. ${ }^{5}$

The decade of the 1920's was spent less in developing new processes than in improving the equipment and expanding the scale of the conventional thermal cracking operations. However, in terms of almost any measure other than originality-reduction of costs, saving of resources, expansion of output - the improvements made in the processes subsequent to their initial application were as significant as the innovations themselves.

It was the next invention and innovation in the historical sequence which most savored of the heroic. By devoting himself and his fortune to the study of catalysis, a French inventor, Eugene Houdry, developed the first practical catalytic cracking process. ${ }^{6}$ Commencing after World War I, Houdry carried out research into the nature of catalysis and its effect upon the cracking operation. It was not until 1927, however, that he first successfully produced motor gasoline from a heavy petroleum fraction. Like the inventors of the continuous thermal cracking processes, Eugene Houdry was not originally employed by an oil company. He differed from them in that he alone directed the subsequent development of the invention into a commercial process. In the early 1930's he sought financial support; with the firms that supported him-the Socony-Mobil and Sun Oil Companies-he established the Houdry Process Corporation. By 1936 the difficulties in the design of the equipment had been overcome to the point where a commercial installation could be made.

The Houdry process was semicontinuous in nature, each of the major vessels being operated in a cycle of reaction (cracking the gas oil) and regeneration (burning the carbon off the catalyst). Product flowed through the vessel only during the reaction stage. It was recog-

${ }^{5}$ During the decade 1910 to 1920 it was relatively easy to obtain patent grants covering advances in the cracking art. It is doubtful that today, with the standard of invention higher, all of the four individuals would have been given patents. It was left for the courts to adjudicate the relative merits of each in a series of patent infringement cases commencing with the installation of the first Dubbs unit and continuing through the useful life of the continuous thermal cracking processes, and for the innovating firms to form patent pools in order to avoid litigation.

${ }^{6}$ The major effect of the thermal cracking processes had been to increase appreciably the yield of motor gasoline from a given amount of crude petroleum. The major effect of the catalytic processes was to improve the quality rather than the quantity of gasoline. Catalytic cracking was, therefore, particularly opportune, for it was at this period that the advantages of high octane gasoline were being appreciated and incorporated in the design of automobile engines. 
nized that it was not efficient to have a single vessel serve both functions because of the difficulty in obtaining the proper operating conditions and in synchronizing the flows. So the Houdry process was significantly altered to make it continuous; the result was Thermofor Catalytic Cracking or the T. C. C. process, first installed in 1944. The T. C. C. process and another derivative of the Houdry process, the Houdriflow, required many inventions, although none of them was as substantial a departure as Houdry's original one. The new idea underlying the T. C. C. process was the existence of two vessels, in one of which the reaction and in the other of which the regeneration were continuously carried out. In later versions of the T. C. C. and in the Houdriflow installed after 1950 the new idea was to elevate the catalyst from the regenerator to the reactor vessel not by means of an endless chain of moving buckets, as originally done, but by means of a gas lift. The two major inventions, the separate reaction and regeneration vessels and the gas lift, were achieved by members of SoconyMobil Oil's research department aided by Houdry Process. The inventions were attributed to no single individual, and the patents were all assigned to the inventors' employers. Invention in the petroleum industry had become institutionalized.

When the Houdry process was recognized to be a very useful one, all the major oil companies other than Socony-Mobil and Sun OilHoudry stockholders-were faced with the choice of adopting it or developing their own catalytic processes. A group of them, led by the Standard Oil (New Jersey), chose the latter course and deliberately tried to invent around the Houdry patents. In the relatively short period of six years they and their associates developed a new process, Fluid Catalytic Cracking, so-called because it incorporated a fluidized catalyst bed. Like the T. C. C. process introduced two years later, it utilized separate vessels for reaction and regeneration. Also like the T. C. C. process, the Fluid process was the result of a cooperative research and development program. It is, therefore, very difficult to ascribe the invention to a group of individuals, let alone a single one. However, the original patent for the fluidized bed was taken out by an independent inventor and oil industry consultant, W. W. Odell. Odell's application for a patent on a process of producing reactions using a fluidized bed of powdered catalyst was made in 1929; in 1936 an application was made to renew the patent to apply the invention to catalytic cracking. The majority of the developmental work, however, was carried out in the five years, 1938-42, preceding the first 
commercial installation. Improvements have been made in the three continuous catalytic cracking processes-the Fluid, the T. C. C., and the Houdriflow. Today they account for nearly all of the gasoline made from heavy hydrocarbons.

I have described a series of inventions and innovations pertaining to the manufacture of motor gasoline from a heavy hydrocarbon material. These inventions and innovations occupied a period of approximately forty-five years from 1913 to the present and permitted the manufacture of products of higher qualities and greater yields at successively lower costs. The processes utilized first heat and pressure and then catalysts to promote the cracking reaction. They were initially noncontinuous and subsequently continuous in operation. In almost all cases the inventions were made by men close to the oil industry but not attached to the major firms.

\section{The Interval between Invention and Innovation}

An invention may be of immediate usefulness or it may be visionary, requiring great advances in technology and tastes before adoption. Similarly, innovation, consisting of many activities with varying ease of accomplishment, may be completed quickly or slowly. With such variety is it possible that the intervals between invention and innovation display any systematic pattern?

First, we might ask what the pattern might be in theory. Let us assume that each of the various activities or events which together comprise an innovation is independent of the others; that the events follow one another in sequence; and that the amount of time required to accomplish each varies randomly, following some common but unspecified probability distribution. The interval for innovation would be the sum of the times for all the events. In statistics the distribution of the sum of a series of observations approaches the normal distribution, no matter what the original distribution of the single events. Finally, if we assume that the number of events comprising the innovation are legion, then we can conclude that the distribution of intervals between invention and innovation will be normal.?

' If we were to consider not the interval between invention and innovation but the probability that, given the invention, the innovation would actually occur, we would derive a different theoretical distribution. As before, innovation is defined as the successful result of several activities: selecting an invention, securing financial backing, establishing an organization, finding a plant, hiring workers, opening markets, etc. If any one of these activities should not be accomplished, then the innovation will not transpire. Therefore the event, innovation, is the product, not the sum, of many independent activities, the product being the correct combination because the resultant (innovation) 
TABLE 1

Time INTERVAL BETWEen INVENTION AND INNOVATION for Nine Cracking Processes

\begin{tabular}{|c|c|c|c|c|c|}
\hline \multicolumn{2}{|l|}{ Invention } & \multicolumn{3}{|c|}{ Innovation } & \multirow{2}{*}{$\begin{array}{c}\text { Interval } \\
\text { Between } \\
\text { Invention } \\
\text { and } \\
\text { Innovation } \\
\text { (years) }\end{array}$} \\
\hline $\begin{array}{l}\text { Nature of } \\
\text { Invention }\end{array}$ & $\begin{array}{l}\text { Date } \\
\text { Made }\end{array}$ & Description & $\begin{array}{l}\text { Name of } \\
\text { Process }\end{array}$ & $\begin{array}{l}\text { Date of First } \\
\text { Commercial } \\
\text { Operation }\end{array}$ & \\
\hline $\begin{array}{l}\text { Distilling } \\
\text { hydrocarbons } \\
\text { with heat and } \\
\text { pressure }\end{array}$ & 1889 & $\begin{array}{l}\text { Batch thermal } \\
\text { cracking }\end{array}$ & Burton & 1913 & 24 \\
\hline $\begin{array}{l}\text { Distilling gas oil } \\
\text { with heat and } \\
\text { pressure }\end{array}$ & 1910 & & & & 3 \\
\hline $\begin{array}{l}\text { Continuous } \\
\text { cracking }\end{array}$ & 1909 & $\begin{array}{c}\text { Continuous } \\
\text { thermal } \\
\text { cracking }\end{array}$ & $\begin{array}{l}\text { Holmes- } \\
\text { Manley }\end{array}$ & 1920 & 11 \\
\hline $\begin{array}{l}\text { Continuous } \\
\text { cracking }\end{array}$ & 1909 & $\begin{array}{c}\text { Continuous } \\
\text { thermal }\end{array}$ & Dubbs & 1922 & 13 \\
\hline $\begin{array}{l}\text { "Clean } \\
\text { circulation" }\end{array}$ & 1919 & cracking & & & \\
\hline $\begin{array}{l}\text { Continuous } \\
\text { cracking }\end{array}$ & 1909 & $\begin{array}{l}\text { Continuous } \\
\text { thermal } \\
\text { cracking }\end{array}$ & $\begin{array}{c}\text { Tube and } \\
\text { Tank }\end{array}$ & 1922 & 13 \\
\hline $\begin{array}{l}\text { Continuous } \\
\text { cracking of } \\
\text { gas oil }\end{array}$ & 1915 & $\begin{array}{l}\text { Continuous } \\
\text { thermal } \\
\text { cracking }\end{array}$ & Cross & 1920 & 5 \\
\hline $\begin{array}{l}\text { Catalytic } \\
\text { cracking of gas } \\
\text { oil and catalyst } \\
\text { regeneration }\end{array}$ & 1927 & $\begin{array}{l}\text { Semi-con- } \\
\text { tinuous } \\
\text { catalytic } \\
\text { cracking }\end{array}$ & Houdry & 1936 & 9 \\
\hline $\begin{array}{l}\text { Fluidized } \\
\text { bed of } \\
\text { catalyst }\end{array}$ & 1929 & $\begin{array}{l}\text { Continuous } \\
\text { catalytic } \\
\text { cracking }\end{array}$ & Fluid & 1942 & 13 \\
\hline $\begin{array}{l}\text { Moving bed } \\
\text { of catalyst; } \\
\text { regeneration }\end{array}$ & 1936 & $\begin{array}{l}\text { Continuous } \\
\text { catalytic } \\
\text { cracking }\end{array}$ & $\begin{array}{l}\text { T.C.C. } \\
\text { (elevator) }\end{array}$ & 1944 & 8 \\
\hline $\begin{array}{l}\text { Gas lift for } \\
\text { catalyst } \\
\text { pellets }\end{array}$ & 1937 & $\begin{array}{l}\text { Continuous } \\
\text { catalytic } \\
\text { cracking }\end{array}$ & $\begin{array}{l}\text { T.C.C. and } \\
\text { Houdriflow } \\
\text { (gas lift) }\end{array}$ & 1950 & 13 \\
\hline
\end{tabular}

is zero (i.e., does not occur) whenever any one of the activities (e.g., financing) is not accomplished. If we assume that the activities occur in sequence, that each activity is independent of the preceding one, and that the probabilities of successful completion of the activities are drawn randomly from a single distribution, then the likelihood of the innovation occurring when a particular activity takes place is dependent upon the value of the likelihood reached previously, and the change in the likelihood of the innovation occurring is a random proportion of the previous value. This is called the law of proportionate effect, and a variable subject to this law follows the log-normal distribution. For a description of the genesis of the log-normal distribution, see $\mathbf{J}$. Aitchison and J. A. C. Brown, The Log Normal Distribution, Cambridge University Press, 1957, pp. 20-23. 
Having hypothesized a pattern to which the intervals between invention and innovation might conform, we shall now see how this compares with the actual pattern. In my study of inventions and innovations in cracking I observed nine commercial processes. The data are summarized in Table 1. This affords us nine time intervals between the two events. In two cases, the Burton and Dubbs processes, I associated two inventions with each innovation. If we credit these as additional observations, we have a total of eleven. Giving each invention equal weight, we obtain for the sample of eleven observations an arithmetic mean interval between invention and innovation of 11.0 years and a median of 11 . For the sample of nine observations the mean is 12.8 years and the median, 13 . The standard deviations are 4.6 and 3.0 , respectively.

Could these observations conceivably have been drawn from a normally distributed population of equivalent mean and standard deviation? With such a small sample it is difficult to answer this question with any degree of assurance. A visual comparison of the actual and theoretical distributions for the sample of eleven observations is given by Figure 1.

In selecting parameters for the theoretical distribution of intervals between invention and innovation we took those derived from our experimental results; we could equally well have calculated them from

FIGURE 1

Frequency Distribution of Intervals Between Eleven Inventions and Innovations in the Petroleum Refining Industry

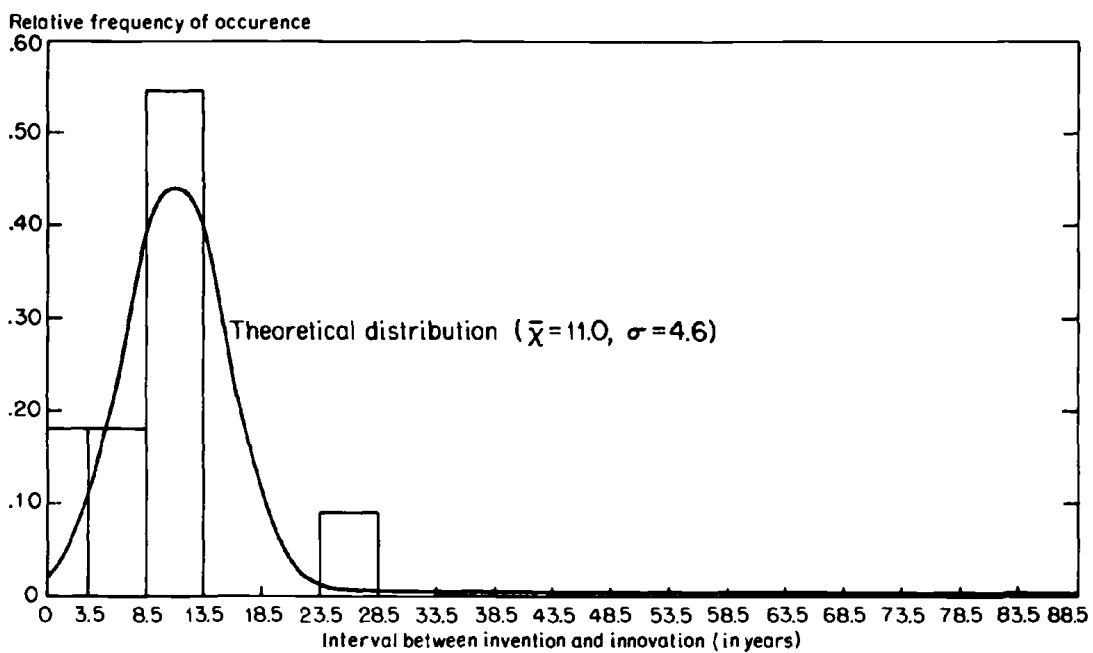


a larger sample drawn from the total universe of innovations. The sample presented in Table 2 was selected on the basis of ease of

TABLE 2

TIME INTERVAL BETWEEN INVENTION AND INNOVATION FOR THIRTY-FIVE Different Products and Processes

\begin{tabular}{|c|c|c|c|c|c|}
\hline \multicolumn{3}{|c|}{ Invention } & \multicolumn{2}{|l|}{ Innovation } & \multirow{2}{*}{$\begin{array}{c}\text { Interval } \\
\text { Between } \\
\text { Invention } \\
\quad \text { and } \\
\text { Innovation } \\
\text { (years) }\end{array}$} \\
\hline Product & Inventor & Date & Firm & Date & \\
\hline Safety razor & Gillette & 1895 & $\begin{array}{l}\text { Gillette Safety Razor } \\
\text { Company }\end{array}$ & 1904 & 9 \\
\hline Fluorescent lamp & Bacquerel & 1859 & $\begin{array}{l}\text { General Electric, } \\
\text { Westinghouse }\end{array}$ & 1938 & 79 \\
\hline Television & Zworykin & 1919 & Westinghouse & 1941 & 22 \\
\hline Wireless telegraph & Hertz & 1889 & Marconi & 1897 & 8 \\
\hline Wireless telephone & Fessenden & 1900 & $\begin{array}{l}\text { National Electric } \\
\text { Signaling Company }\end{array}$ & 1908 & 8 \\
\hline Triode vacuum tube & de Forest & 1907 & $\begin{array}{l}\text { The Radio Telephone } \\
\text { and Telegraph } \\
\text { Company }\end{array}$ & 1914 & 7 \\
\hline Radio (oscillator) & de Forest & 1912 & Westinghouse & 1920 & 8 \\
\hline Spinning jenny & Hargreaves & 1765 & Hargreaves' & 1770 & 5 \\
\hline $\begin{array}{l}\text { Spinning machine } \\
\text { (water frame) }\end{array}$ & Highs & 1767 & Arkwright's & 1773 & 6 \\
\hline Spinning mule & Crompton & 1779 & $\begin{array}{l}\text { Textile machine } \\
\text { manufacturers }\end{array}$ & 1783 & 4 \\
\hline Steam engine & Newcommen & 1705 & English firm & 1711 & 6 \\
\hline Steam engine & Watt & 1764 & Boulton and Watt & 1775 & 11 \\
\hline Ball-point pen & I. J. Biro & 1938 & Argentine firm & 1944 & 6 \\
\hline Cotton picker & A. Campbell & 1889 & $\begin{array}{l}\text { International } \\
\text { Harvester }\end{array}$ & 1942 & 53 \\
\hline $\begin{array}{l}\text { Crease-resistant } \\
\text { fabrics }\end{array}$ & $\begin{array}{l}\text { Company } \\
\text { scientists }\end{array}$ & 1918 & $\begin{array}{l}\text { Tootal Broadhurst Lee } \\
\text { Company, Ltd. }\end{array}$ & 1932 & 14 \\
\hline DDT & $\begin{array}{l}\text { Company } \\
\text { chemists }\end{array}$ & 1939 & J. R. Geigy Co. & 1942 & 3 \\
\hline $\begin{array}{l}\text { Electric } \\
\text { precipitation }\end{array}$ & Sir O. Lodge & 1884 & Cottrell's & 1909 & 25 \\
\hline Freon refrigerants & $\begin{array}{l}\text { T. Midgley, Jr. } \\
\text { and A. L. Henne }\end{array}$ & 1930 & $\begin{array}{l}\text { Kinetic Chemicals, } \\
\text { Inc. (General } \\
\text { Motors and Du Pont) }\end{array}$ & 1931 & 1 \\
\hline Gyro-compass & Foucault & 1852 & Anschütz-Kaempfe & 1908 & 56 \\
\hline Hardening of fats & W. Normann & 1901 & $\begin{array}{l}\text { Crosfield's of } \\
\text { Warrington }\end{array}$ & 1909 & 8 \\
\hline Jet engine & Sir F. Whittle & 1929 & Rolls Royce & 1943 & 14 \\
\hline Turbo-jet engine & H. von Ohain & 1934 & Junkers & 1944 & 10 \\
\hline Long playing record & P. Goldmark & 1945 & Columbia Records & 1948 & 3 \\
\hline Magnetic recording & V. Poulsen & 1898 & $\begin{array}{l}\text { American Tele- } \\
\text { graphone Co. }\end{array}$ & 1903 & 5 \\
\hline Plexiglas, lucite & W. Chalmers & 1929 & $\begin{array}{l}\text { Imperial Chemical } \\
\text { Industries }\end{array}$ & 1932 & 3 \\
\hline
\end{tabular}

(continued) 
CASE STUDIES

TABLE 2 (concluded)

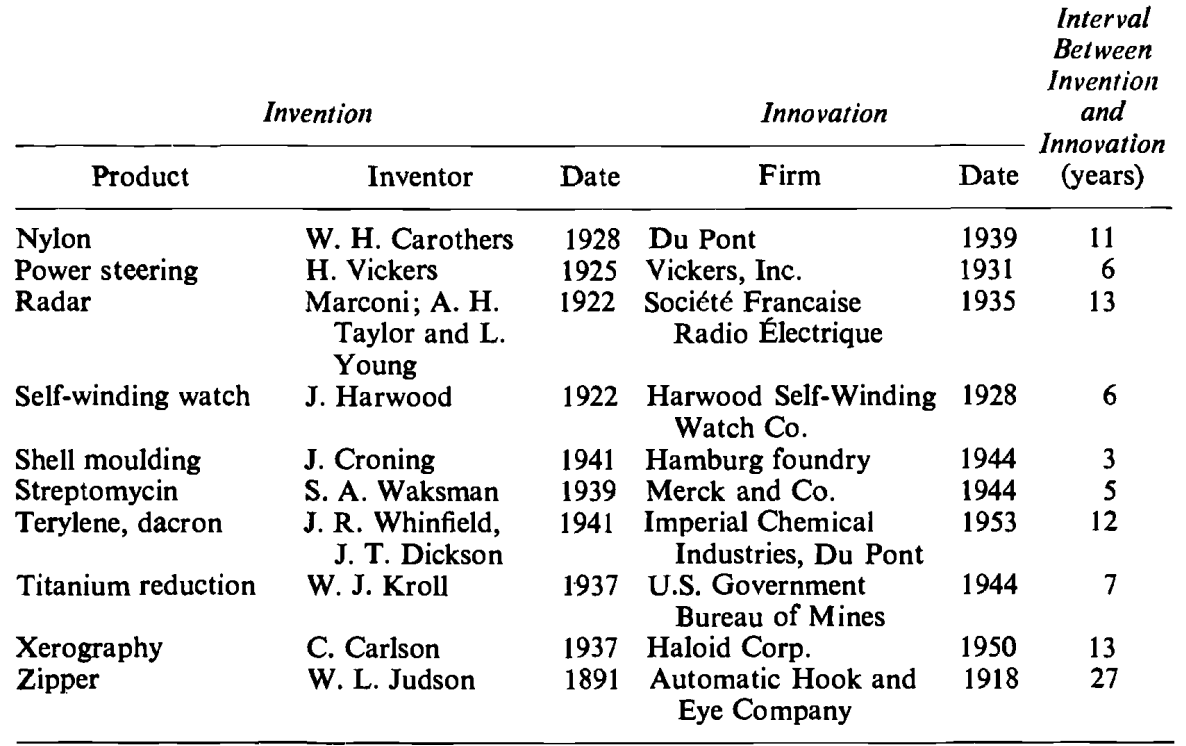

SouRcE: Safety razor: G. B. Baldwin, "The Invention of the Modern Safety Razor: A Case Study of Industrial Innovation," Explorations in Entrepreneurial History, December 1951, p. 74

Fluorescent lamp: A. A. Bright and W. R. Maclaurin, "Economic Factors Influencing the Development and Introduction of the Fluorescent Lamp," Journal of Political Economy, October 1943, p. 436.

Television: W. R. Maclaurin, "Patents and Technical Progress-A Study of Television," Journal of Political Economy, April 1950, pp. 145-153.

Wireless telegraph, wireless telephone, triode vacuum tube, oscillator: W. R. Maclaurin, Invention and Innovation in the Radio Industry, New York, Macmillan, 1949, pp. 15-16, 33, 59, 67, 74, 85, 112.

Spinning jenny, water frame, spinning mule, steam engines: P. Mantoux, The Industrial Revolution in the Eighteenth Century, 2nd ed., New York, Macmillan, 1927, pp. 220-223, 228-235, 241-243, 323-324, 327-336.

Remainder: J. Jewkes, D. Sawers and R. Stillerman, The Sources of Invention, London, Macmillan, 1958, pp. 263-410.

access to the dates of invention (the earliest conception of the product in substantially its commercial form) and innovation (the first commercial application or sale). The individual observations may not be wholly accurate and the total is certainly not comprehensive. Moreover, placing in one class different numbers of observations from different industries at different points in chronological time may produce bias, for such factors as the industry, its stage of development, 
FIGURE 2

Frequency Distribution of Intervals Between Thirty-Five Inventions and Innovations in All Industries

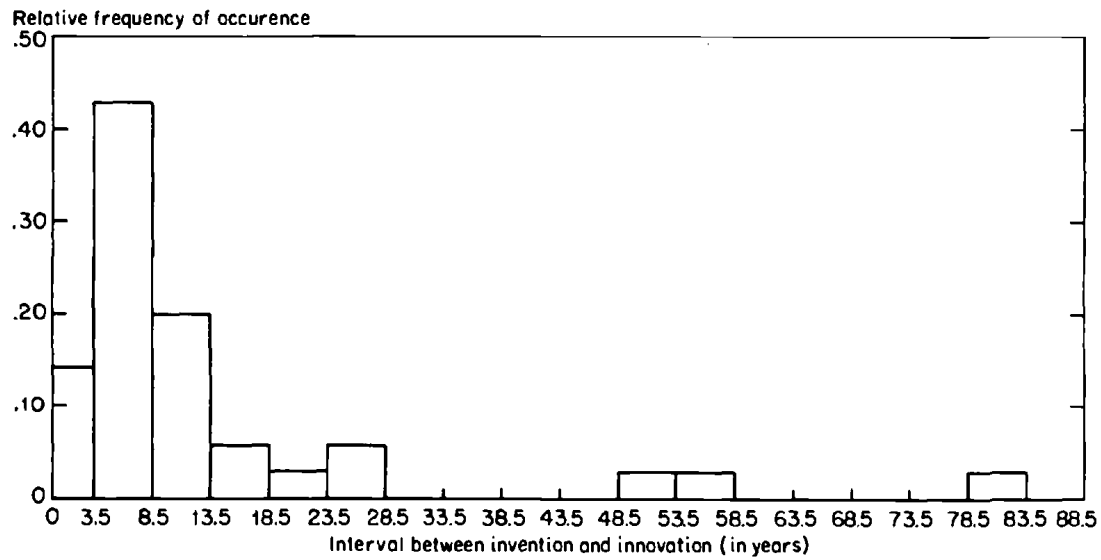

the size of the market, etc., may affect the interval between invention and innovation. ${ }^{8}$

The sample of thirty-five innovations yields an arithmetic mean of 13.6 years and a standard deviation of 16.3 , an unlikely pair of statistics for a sample drawn from a normal distribution (see Figure 2). (If we were to eliminate the observation of the fluorescent lamp, the mean would be reduced to 11.6 years and the standard deviation to 12.3.) Looking casually at the data we can discern some variation among classes of innovations. Mechanical innovations appear to require the shortest time interval, with chemical and pharmaceutical innovations next. Electronic innovations took the most time. The interval appears shorter when the inventor himself attempts to innovate than when he is content merely to reveal the general concept. At any rate, whatever the reasons for the wide temporal variation, we cannot make any sophisticated comparison between the sample of all innovations and our own sample from petroleum refining using

\footnotetext{
${ }^{8}$ In mathematical terms we have assumed that the interval between invention and innovation is equal to a constant, $a$, plus an error term, $u$, where $u$ is a random variable distributed normally about a zero mean. If $u$ is not really random, i.e., if part of the variation in $u$ can be explained by explicit factors, $x$, such as the industry, etc., then the $x$ should be included in the relationship, too. The proper relationship would then be
}

$$
y=f\left(a, x_{1}, x_{2} \ldots x_{n}\right) .
$$


statistics applicable to normal distributions. The difference in the standard deviations of the two samples (13.6 vs. 16.3 years) does indicate, however, that the intervals between invention and innovation in the petroleum refining industry are less varied than those in industry as a whole.

\section{Returns to the Inventor and the Innovator}

We cannot draw any inferences as to what motivated the inventor merely by looking at the consequences of an invention, for the forces that influence behavior are complex and difficult to discover. Presuming, however, that the inventors hoped to make a profit from their inventions, we can see if these hopes were justified by the actual events. Again our sample of cracking innovations is not a perfect one, although this time it is not its small size that detracts from the generality of the results so much as the fact that all the innovations were very successful, this being the criterion for their selection.

Table 3 presents the relevant information; with the exception of the Holmes-Manley process for which the author made no estimates, the innovations cost in total roughly $\$ 60$ million and returned roughly $\$ 2,200$ million, with more still to come from the continuous catalytic cracking processes. The figures on returns from innovations are very crude, as one might expect. They are biased upward because all the returns from operating the processes are allocated to the innovations and none to the capital invested in the plant and equipment; they are biased downward for operating companies because the innovating firm's rate of profit was assumed to be equal to the royalty rate it charged others. These two biases somewhat offset each other, but the net effect cannot be estimated.

Individually and collectively the invention of cracking processes was a profitable activity. The amounts and variation in costs were not very great; only for Eugene Houdry was the sum substantial. The variation in returns, however, was wide, running all the way from the standard wages paid to engineers and scientists to many millions of dollars. The majority of the personal profits were made before 1930 , for the subsequent institutionalization of research has deprived the corporate inventor of the prospect of a very large return.

Perhaps the most significant observation is the lack of correlation between what the inventor and the innovator received. In fact, the two sums are, if anything, inversely correlated. The explanation may lie in the size and the organization of the innovating firm, and in the 
THE PETROLEUM REFINING INDUSTRY

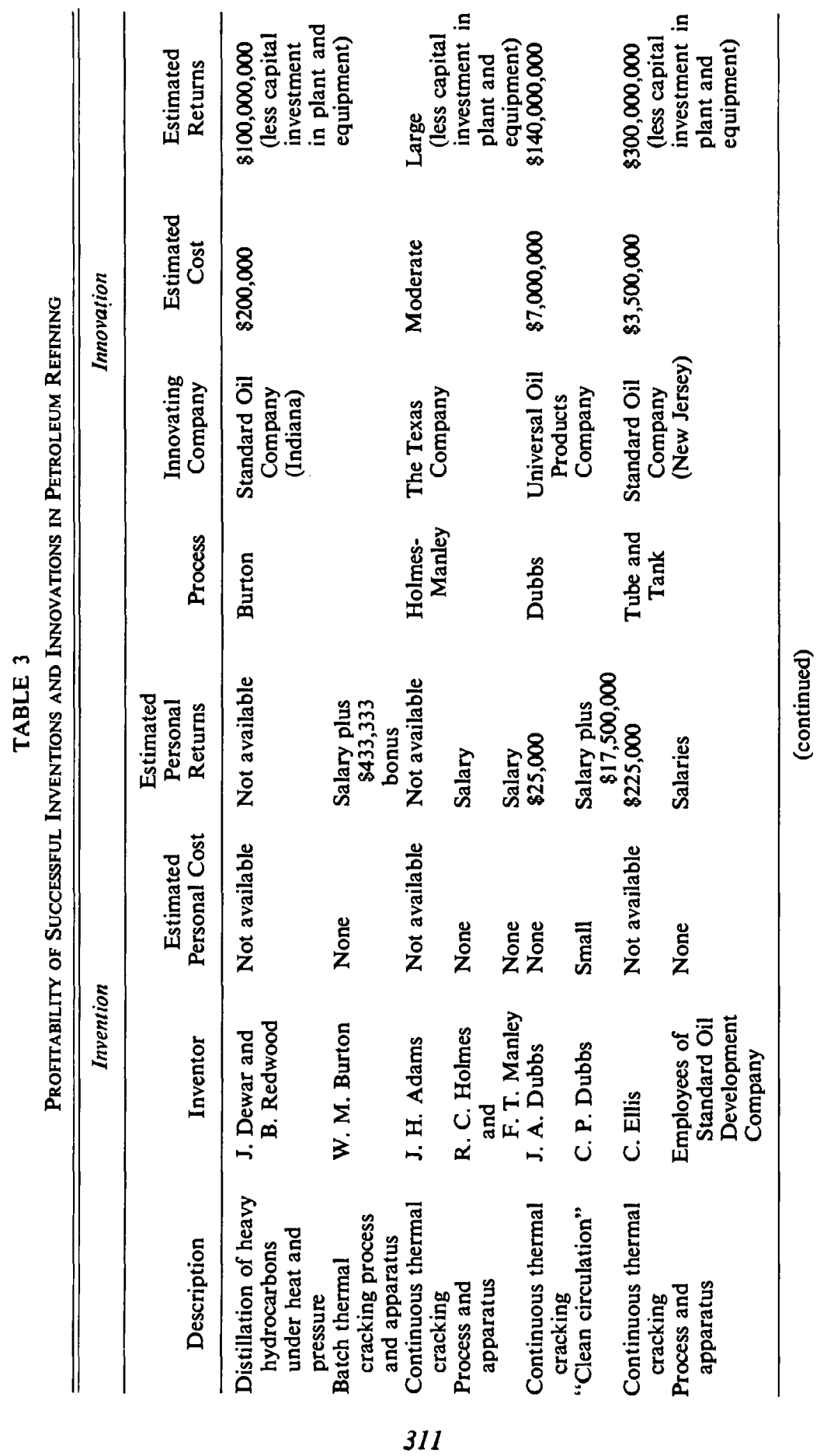


CASE STUDIES

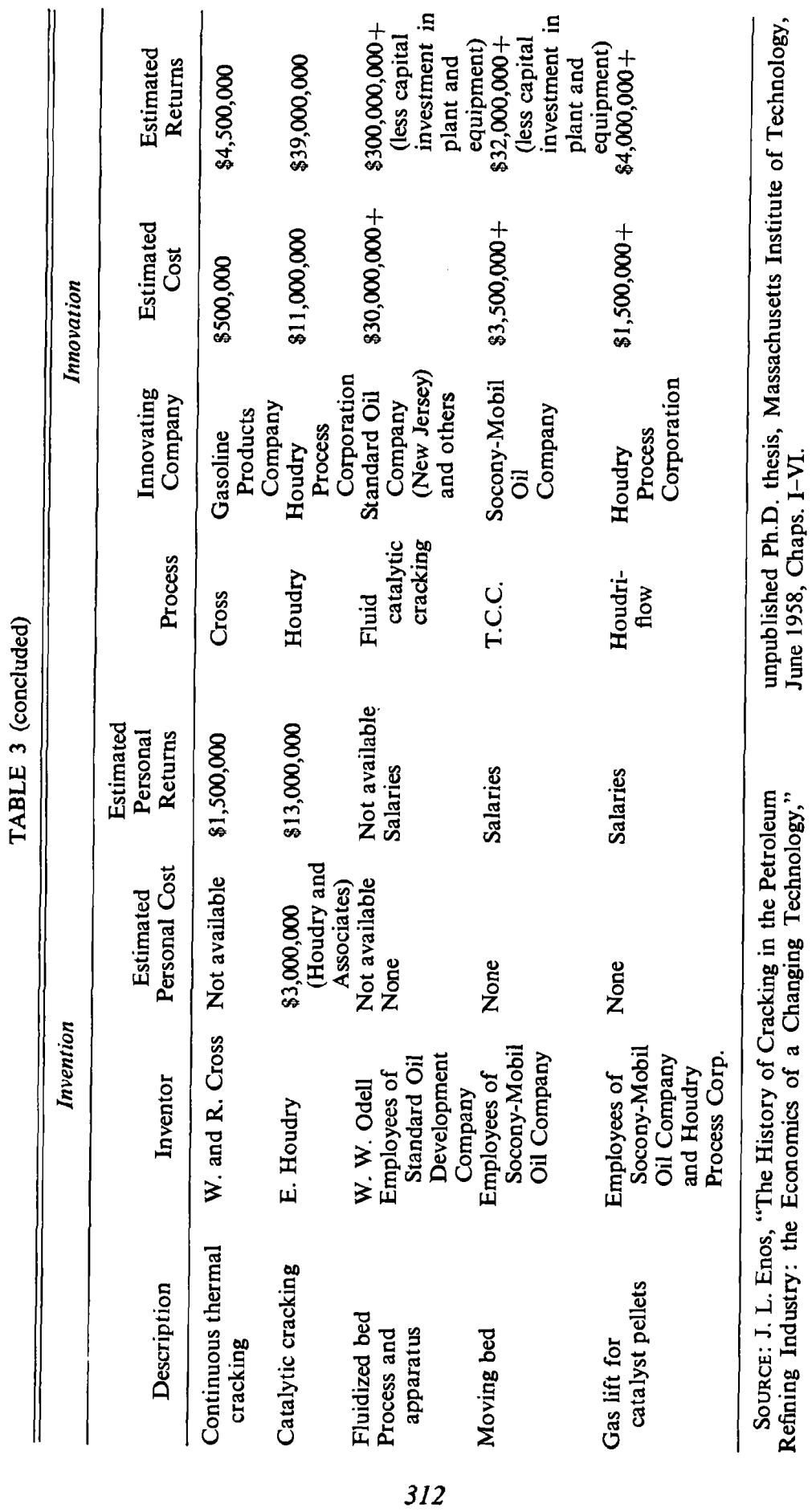


extent to which the inventor was associated with the innovation. The largest firms will receive the greatest absolute returns because they can apply innovations most widely. They are also the firms that are most likely to have permanent research and development organizations with salaried inventors. Their over-all returns, however, from research and development will not be as substantial as the history of the cracking processes would intimate, for they are paying the salaries of uninventive investigators as well.

We might expect that an inventor who helped to apply his invention would receive a greater return than one who was not associated with the innovation. Examining the cracking inventions, I found five inventors-Burton, Holmes and Manley, Carbon P. Dubbs, and Houdry-who also filled certain portions of the role of innovator; and eight-Dewar and Redwood, Adams, J. A. Dubbs, Ellis, W. and R. Cross, and Odell-who had little or no connection with the innovating firm. In the remaining four instances no single individual was responsible for the inventions; the ideas flowed from the research departments of the innovating firms. From the data in Table 3 it appears that those inventors who also took part in the subsequent innovations did receive greater returns than the others, but again the sample is so small that little confidence can be placed in the conclusion.

\section{Changes in Factor Proportions}

In an economy, scarce resources are allocated so as to satisfy conflicting and limitless needs. Through invention, a given output of product can be produced with a smaller total consumption of resources. Invention, by saving resources over-all, increases satisfaction and justifies itself.

One way of saving resources is to economize simultaneously on each of the factors of production in such a way that factor proportions remain unchanged. An invention of this nature would permit the same amount of product to be made with less of factor A, less of $B$, less of $C$, and so on, all in the same proportion. The greater the total saving, the more profitable the invention. If the invention has negligible effect on the total demand for any of the factors of production or if factor supply elasticities are all equal, then there will be no changes in the distribution of income.

The second way of saving resources through inventions is to substitute abundant resources for those which are scarce. In this case, 
factor proportions are changed. It is possible that less of each of the factors may be used; it is equally possible that more of the abundant resources may be used than before, together with less of the scarce ones. If the former, the invention will surely be adopted; if the latter, it will be adopted only if total costs of production are reduced. The money saved by economizing on the scarce factors must more than offset the increase in cost consequent upon using more of the abundant factors.

It might be well to define "abundant" and "scarce" precisely. A scarce factor is one whose cost is expected in the future to increase relative to that of the other factors. This could be a function of present supply elasticities. Assuming no change in the supply schedules through time, the scarce factor is the one with the more inelastic supply schedule. The relatively rising cost may also result from changing conditions on the supply side of the factor, i.e. increasingly inelastic supply schedules through time.

If relative factor prices are expected to change in the future, for whatever reason, new techniques would be developed which would substitute the abundant factor for the scarce one. For example, if in the future the price of labor is expected to rise relative to that of capital, we would argue that invention would proceed in the direction of substituting capital for labor.

Theoretically, this argument is indisputable. The important point, however, is whether or not it is consequential. If it is, the direction of invention in the future can be predicted with some accuracy. Quite easily, one can prognosticate future rates of growth for the various factors of production. In the United States, for example, it is believed that the stock of capital will grow faster than population will. The direction of invention, therefore, will be to substitute capital for labor.

Let us now see if abundant resources have been substituted for scarce ones, using data from four of the cracking process innovations. ${ }^{9}$ First we shall have to establish the trends in the appropriate factor prices. The inputs to petroleum cracking are raw materials, labor, capital, and fuel. In Table 4 price series for these factors are given first on an index number basis and then relative to labor. The labor price series is derived from various wage statistics on the average

\footnotetext{
${ }^{9}$ Because several of the nine cracking innovations were very similar in terms of factor consumption and costs, we have only four entirely different sets of conditions. In their economic aspects the four continuous thermal cracking processes-Holmes-Manley, Dubbs, Tube and Tank, and Cross-were almost identical, particularly toward the end of their sway, as are the three continuous catalytic cracking processes today.
} 
hourly rate paid to refinery workers. The fuel price is equal to the cost of heavy fuel oil; that of raw material, to the cost of gas-oil. Two different price series are tabulated for capital: one was derived from statistics on the average rate of return on investment for the petroleum industry as a whole, and the other from the cost of construction of refinery equipment. The assumption underlying all the price series is that additional resources may be acquired at a cost equal to the return on the outstanding stock.

Looking at Table 4, we observe that the price of labor has risen substantially since 1913, the rise being interrupted only once, during the depression of the 1930's. The other price series moved more erratically, although some trends can be discovered. The price of fuel fluctuated at a relatively high level until the mid-1920's, after which it declined substantially until 1931. From 1931 until 1948 it rose steadily at about the same rate as the price of labor. It declined until 1953 and then appeared to be rising again. For raw material price we have no observations for the period from 1923 to 1938 , but during the other years the general direction of movement was similar to that of the price of fuel, although the fluctuations were milder. Our two series for the price of capital show different behavior. That based on construction costs follows the same general pattern as labor, although with milder fluctuations. The series based on rate of return shows the greatest fluctuations of all, the price varying from a negative figure in 1931-revealing losses for the industry as a whole-to a figure in 1948 over four times that achieved in 1939. It reveals a temporal pattern similar to that of the fuel price, fluctuating at high levels from 1919 to 1922 , declining rapidly until 1931 , rising steadily until a peak was reached in 1948, and remaining at a relatively high level thereafter.

Relative to labor, all prices fell from 1913 to the middle of the depression, those of raw material and fuel falling most rapidly, that of capital less so. Excepting the war years, from the middle of the 1930's until about 1948 construction cost rose less rapidly than labor whereas the price of fuel and the rate of return rose more rapidly, the latter rising the most rapidly of all. During the 1940's the price of raw material rose relative to wage rates at a rate midway between those of fuel and capital. Since 1948 the relative prices of all three factors have declined relative to labor, rate of return the most, construction cost the least.

We shall now turn from changes in relative factor prices to changes 


\section{CASE STUDIES}

TABLE 4

Changes in Factor Prices, Petroleum Refining, 1913-55

\begin{tabular}{|c|c|c|c|c|c|c|c|c|c|}
\hline \multirow[b]{2}{*}{ YEAR } & \multirow[b]{2}{*}{ Labor } & \multirow[b]{2}{*}{ Fuel } & \multicolumn{3}{|c|}{$\begin{array}{l}\text { PRICE INDEXES } \\
(1939=100)\end{array}$} & \multirow[b]{2}{*}{ Fuel } & \multicolumn{3}{|c|}{$\begin{array}{l}\text { RELATIVE PRICES } \\
\text { ratios, relative to labor) } \\
\text { Capital }\end{array}$} \\
\hline & & & $\begin{array}{c}\text { Raw } \\
\text { Material }\end{array}$ & $\begin{array}{l}\text { Con- } \\
\text { struction }\end{array}$ & $\begin{array}{l}\text { Rate of } \\
\text { Return }\end{array}$ & & $\begin{array}{c}\text { Raw } \\
\text { Material }\end{array}$ & $\begin{array}{l}\text { Con- } \\
\text { struction }\end{array}$ & $\begin{array}{l}\text { Rate of } \\
\text { Return }\end{array}$ \\
\hline $\begin{array}{l}1913 \\
1914\end{array}$ & $\begin{array}{l}\text { n.a. } \\
\text { n.a. }\end{array}$ & $\begin{array}{l}119 \\
108\end{array}$ & $\begin{array}{l}79.6 \\
78.6\end{array}$ & $\begin{array}{l}52.1 \\
47.3\end{array}$ & $\begin{array}{l}\text { n.a. } \\
\text { n.a. }\end{array}$ & $\begin{array}{l}\text { n.a. } \\
\text { n.a. }\end{array}$ & $\begin{array}{l}\text { n.a. } \\
\text { n.a. }\end{array}$ & $\begin{array}{l}\text { n.a. } \\
\text { n.a. }\end{array}$ & $\begin{array}{l}\text { n.a. } \\
\text { n.a. }\end{array}$ \\
\hline $\begin{array}{l}1915 \\
1916 \\
1917 \\
1918 \\
1919\end{array}$ & $\begin{array}{l}30.2 \\
30.4 \\
47.8 \\
58.9 \\
73.0\end{array}$ & $\begin{array}{r}111 \\
161 \\
155 \\
203 \\
88\end{array}$ & $\begin{array}{l}83.9 \\
134 \\
180 \\
210 \\
220\end{array}$ & $\begin{array}{r}49.2 \\
62.7 \\
84.9 \\
99.3 \\
105.6\end{array}$ & $\begin{array}{c}\text { n.a. } \\
\text { n.a. } \\
\text { n.a. } \\
\text { n.a. } \\
268\end{array}$ & $\begin{array}{l}3.7 \\
5.3 \\
3.2 \\
3.4 \\
1.2\end{array}$ & $\begin{array}{l}2.7 \\
4.4 \\
3.8 \\
3.6 \\
3.0\end{array}$ & $\begin{array}{l}1.6 \\
2.1 \\
1.8 \\
1.7 \\
1.4\end{array}$ & $\begin{array}{l}\text { n.a. } \\
\text { n.a. } \\
\text { n.a. } \\
\text { n.a. } \\
3.7\end{array}$ \\
\hline $\begin{array}{l}1920 \\
1921 \\
1922 \\
1923 \\
1924\end{array}$ & $\begin{array}{l}83.0 \\
85.0 \\
77.5 \\
78.5 \\
79.0\end{array}$ & $\begin{array}{c}400 \\
167 \\
138 \\
\text { n.a. } \\
272\end{array}$ & $\begin{array}{c}400 \\
181 \\
175 \\
175 \\
\text { n.a. }\end{array}$ & $\begin{array}{r}139.1 \\
104.0 \\
82.7 \\
99.7 \\
103.9\end{array}$ & $\begin{array}{l}292 \\
22.6 \\
134 \\
116 \\
137\end{array}$ & $\begin{array}{l}4.8 \\
2.0 \\
1.8 \\
\text { n.a. } \\
3.4\end{array}$ & $\begin{array}{l}4.8 \\
2.1 \\
2.2 \\
2.2 \\
\text { n.a. }\end{array}$ & $\begin{array}{l}1.7 \\
1.2 \\
1.1 \\
1.3 \\
1.3\end{array}$ & $\begin{array}{l}0.27 \\
0.27 \\
1.7 \\
1.5 \\
1.7\end{array}$ \\
\hline $\begin{array}{l}1925 \\
1926 \\
1927 \\
1928 \\
1929\end{array}$ & $\begin{array}{l}78.0 \\
78.0 \\
79.1 \\
\text { n.a. } \\
\text { n.a. }\end{array}$ & $\begin{array}{c}250 \\
174 \\
127 \\
91.1 \\
77.3\end{array}$ & $\begin{array}{l}\text { n.a. } \\
\text { n.a. } \\
\text { n.a. } \\
\text { n.a. } \\
\text { n.a. }\end{array}$ & $\begin{array}{r}101.0 \\
99.4 \\
97.5 \\
97.8 \\
95.9\end{array}$ & $\begin{array}{c}200 \\
197 \\
92.8 \\
174 \\
179\end{array}$ & $\begin{array}{l}3.2 \\
2.2 \\
1.6 \\
\text { n.a. } \\
\text { n.a. }\end{array}$ & $\begin{array}{l}\text { n.a. } \\
\text { n.a. } \\
\text { n.a. } \\
\text { n.a. } \\
\text { n.a. }\end{array}$ & $\begin{array}{l}1.3 \\
1.3 \\
1.2 \\
\text { n.a. } \\
\text { n.a. }\end{array}$ & $\begin{array}{l}2.6 \\
2.5 \\
1.2 \\
\text { n.a. } \\
\text { n.a. }\end{array}$ \\
\hline $\begin{array}{l}1930 \\
1931 \\
1932 \\
1933 \\
1934\end{array}$ & $\begin{array}{l}\text { n.a. } \\
\text { n.a. } \\
\text { n.a. } \\
67.1 \\
78.0\end{array}$ & $\begin{array}{l}75.6 \\
42.0 \\
50.5 \\
60.1 \\
92.3\end{array}$ & $\begin{array}{l}\text { n.a. } \\
\text { n.a. } \\
\text { n.a. } \\
\text { n.a. } \\
\text { n.a. }\end{array}$ & $\begin{array}{l}91.8 \\
84.7 \\
73.9 \\
74.0 \\
81.8\end{array}$ & $\begin{array}{l}80.6 \\
19.8 \\
20.2 \\
27.0 \\
53.7\end{array}$ & $\begin{array}{l}\text { n.a. } \\
\text { n.a. } \\
\text { n.a. } \\
0.90 \\
1.2\end{array}$ & $\begin{array}{l}\text { n.a. } \\
\text { n.a. } \\
\text { n.a. } \\
\text { n.a. } \\
\text { n.a. }\end{array}$ & $\begin{array}{l}\text { n.a. } \\
\text { n.a. } \\
\text { n.a. } \\
1.1 \\
1.0\end{array}$ & $\begin{array}{l}\text { n.a. } \\
\text { n.a. } \\
\text { n.a. } \\
0.40 \\
0.69\end{array}$ \\
\hline $\begin{array}{l}1935 \\
1936 \\
1937 \\
1938 \\
1939\end{array}$ & $\begin{array}{c}82.1 \\
84.7 \\
96.7 \\
100 \\
100\end{array}$ & $\begin{array}{c}94.4 \\
92.3 \\
115 \\
107 \\
100\end{array}$ & $\begin{array}{c}\text { n.a. } \\
\text { n.a. } \\
\text { n.a. } \\
115 \\
100\end{array}$ & $\begin{array}{c}81.8 \\
87.9 \\
97.4 \\
100 \\
100\end{array}$ & $\begin{array}{c}96.2 \\
139 \\
185 \\
90.7 \\
100\end{array}$ & $\begin{array}{l}1.1 \\
1.1 \\
1.2 \\
1.1 \\
1.0\end{array}$ & $\begin{array}{l}\text { n.a. } \\
\text { n.a. } \\
\text { n.a. } \\
1.2 \\
1.0\end{array}$ & $\begin{array}{l}1.0 \\
1.0 \\
1.0 \\
1.0 \\
1.0\end{array}$ & $\begin{array}{l}1.2 \\
1.6 \\
1.9 \\
0.91 \\
1.0\end{array}$ \\
\hline $\begin{array}{l}1940 \\
1941 \\
1942 \\
1943 \\
1944\end{array}$ & $\begin{array}{l}101 \\
107 \\
118 \\
125 \\
130\end{array}$ & $\begin{array}{l}120 \\
130 \\
135 \\
138 \\
138\end{array}$ & $\begin{array}{l}98.4 \\
105 \\
108 \\
103 \\
103\end{array}$ & $\begin{array}{l}101 \\
104 \\
109 \\
113 \\
115\end{array}$ & $\begin{array}{l}122 \\
165 \\
124 \\
154 \\
183\end{array}$ & $\begin{array}{l}1.2 \\
1.2 \\
1.1 \\
1.1 \\
1.1\end{array}$ & $\begin{array}{l}0.98 \\
0.98 \\
0.92 \\
0.82 \\
0.79\end{array}$ & $\begin{array}{l}1.0 \\
0.97 \\
0.92 \\
0.91 \\
0.88\end{array}$ & $\begin{array}{l}1.2 \\
1.5 \\
1.1 \\
1.2 \\
1.4\end{array}$ \\
\hline $\begin{array}{l}1945 \\
1946 \\
1947 \\
1948 \\
1949\end{array}$ & $\begin{array}{l}134 \\
148 \\
162 \\
185 \\
194\end{array}$ & $\begin{array}{l}138 \\
169 \\
268 \\
348 \\
200\end{array}$ & $\begin{array}{l}103 \\
123 \\
191 \\
274 \\
219\end{array}$ & $\begin{array}{l}117 \\
131 \\
153 \\
173 \\
182\end{array}$ & $\begin{array}{l}165 \\
202 \\
300 \\
424 \\
256\end{array}$ & $\begin{array}{l}1.0 \\
1.1 \\
1.7 \\
1.9 \\
1.0\end{array}$ & $\begin{array}{l}0.77 \\
0.83 \\
1.2 \\
1.5 \\
1.1\end{array}$ & $\begin{array}{l}0.87 \\
0.89 \\
0.94 \\
0.94 \\
0.94\end{array}$ & $\begin{array}{l}1.2 \\
1.4 \\
1.9 \\
3.3 \\
1.3\end{array}$ \\
\hline $\begin{array}{l}1950 \\
1951 \\
1952 \\
1953 \\
1954\end{array}$ & $\begin{array}{l}200 \\
216 \\
228 \\
240 \\
246\end{array}$ & $\begin{array}{l}233 \\
256 \\
171 \\
164 \\
186\end{array}$ & $\begin{array}{l}234 \\
240 \\
230 \\
224 \\
236\end{array}$ & $\begin{array}{l}191 \\
205 \\
213 \\
227 \\
235\end{array}$ & $\begin{array}{l}287 \\
311 \\
270 \\
268 \\
241\end{array}$ & $\begin{array}{l}1.2 \\
1.2 \\
0.75 \\
0.68 \\
0.76\end{array}$ & $\begin{array}{l}1.2 \\
1.1 \\
1.0 \\
0.45 \\
0.97\end{array}$ & $\begin{array}{l}0.95 \\
0.95 \\
0.93 \\
0.95 \\
0.95\end{array}$ & $\begin{array}{l}1.4 \\
1.4 \\
1.2 \\
1.1 \\
0.98\end{array}$ \\
\hline 1955 & 255 & 246 & 245 & 240 & 252 & 0.96 & 0.96 & 0.94 & 0.99 \\
\hline
\end{tabular}


SourCE: Labor, Fuel, Raw Material and Construction Price Indexes: J. L. Enos, "The History of Cracking in the Petroleum Refining Industry," Tables 1, 2, 3, and 4, pp. 509-516.

Rate of Return, 1923-1955: Rate of return on net worth for the petroleum industry, Petroleum Facts and Figures, American Petroleum Institute, 9th ed., 1950, p. 442; 12th ed., 1956, p. 341, changed to index numbers on the basis $1939=100$. 1919-1922: Income after taxes as a percent of capital plus surplus for fifty-two large petroleum refiners, R. C. Epstein, Industrial Profits in the United States, New York, NBER, 1934, App. Table 6, pp. 622, 625 and 632, placed on a similar index number basis.

n.a. $=$ not available.

in factor proportions. In order to take advantage of all the data on cracking, we shall look at the entire sweep of technological progress.

Let us arbitrarily divide technological progress into two phases, the alpha and the beta. The alpha phase will consist of the invention, its succeeding development in both laboratory and pilot operations, and finally its installation or production in the first commercial plant. At the end of the alpha phase it is in competition with the product of existing processes. Therefore it is possible at this stage to measure its performance in economic terms. The beta phase consists of the improvement of the innovation. Improvements can be of three types: the construction of larger units to take advantage of inherent economies of scale; the adoption of ancillary advances by other industries, and the increase in operating skill or know-how. The alpha phase is quite similar to Schumpeter's "innovation," for it is the innovator who carries the development of the process or the product through its first commercial application. The innovator may also carry the development into the beta phase by making additional improvements; equally likely, it may be imitators who recognize that the original design or operation is not necessarily the best. Schumpeter, by using the terms innovators and imitators, implied that the latter firms make less of a technical contribution. This is not necessarily so, for the beta phase of technological progress may be as significant as the alpha, especially in highly technical industries where considerable advantage can be gained from the skillful application of the art.

In Table 5 factor inputs and factor proportions for four different cracking processes are listed both at the end of the alpha phase, when the first commercial application was made, and at the end of the beta, when improvements virtually ceased. Since each process innovation in the sequence tended to replace immediately the process already in existence, the end of the beta phase of the existing process was caused by and was coincidental with the end of the alpha phase of the new one. 


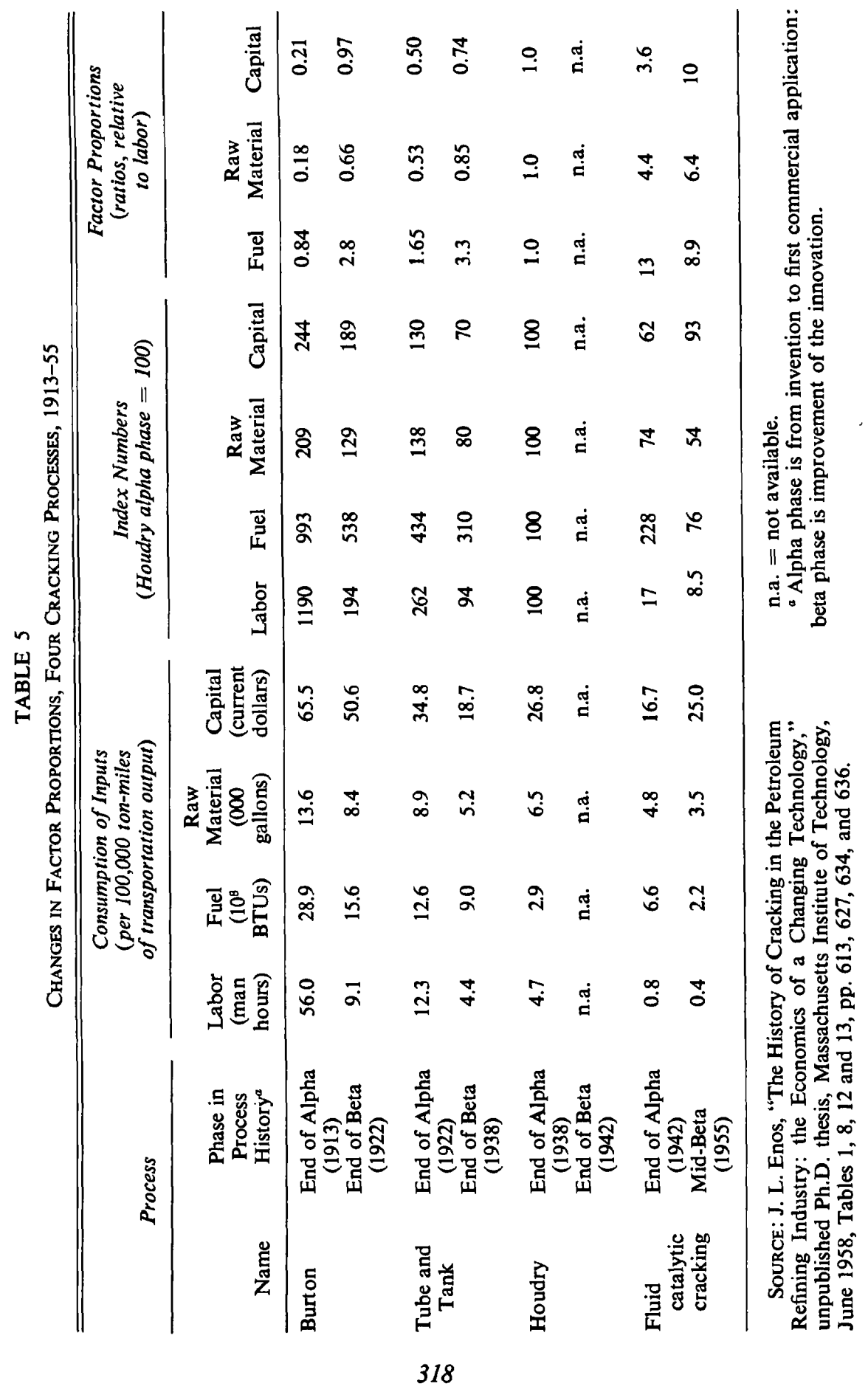


One conclusion that we can draw from the data in Table 5 is that the beta phase is as significant in its economic effects as is the alpha. There appear to be greater reductions in factor inputs, per unit of output, when a process is improved than when it is supplanted by a better one. ${ }^{10}$ Another conclusion is that technological progress has achieved an absolute reduction in each of the factors of production, the reduction being relatively greatest in the consumption of labor, least in capital, and intermediate in raw material and fuel. Taking the whole period 1913 to 1955 , the ratios of factor consumption at the beginning to those at the end are 140:1 for labor, 14:1 for fuel, 4:1 for raw material, and 2.5:1 for capital. The over-all trend in factor substitution has been capital for raw material for fuel for labor.

When we examined factor prices, we were able to make only one generalization concerning trends in relative price changes for the entire period 1913-55-that the price of labor has risen relative to all the others. Comparing the trend in the relative price of labor with the trend in the relative consumption of labor, we find that they move in opposite directions, the former rising while the latter falls. The factor that increased most in price was the factor that was reduced most in use.

Although this generalization appears to hold for the complete act of technological progress, it does not hold for the alpha and beta components, invention-innovation and improvement. Comparing the alpha and beta stages of a single process, we find that in every instance except one (the consumption of fuel in the Fluid Catalytic Cracking process) the direction of process improvement was to substitute the other factors of production for labor. Comparing the alpha stage of one process with the beta stage of the earlier one, however, we find the contrary result. In two of the three cases (Tube and Tank vs. Burton and Houdry vs. Tube and Tank) representing six of the nine instances, the direction of invention-innovation was to substitute, relatively, the scarcest factor, labor, for the other factors of production. Invention-innovation may well be neutral in its effect upon factor proportions, while improvement consists of factor substitution. Only in the beta phase of technological progress is it the scarcest factor that is economized the most.

${ }^{10}$ This argument is developed to a greater extent in the author's paper, "A Measure of the Rate of Technological Progress in the Petroleum Refining Industry," Journal of Industrial Economics, June 1958, pp. 187-194. 
Let us neglect labor and look at the changes in proportions and in the relative prices of the other factors. An assumption of perfect foresight about changes in relative factor prices on the part of inventors is too unrealistic; a better one might be that inventors, equipped only with past data and with imperfect memories, assume that relative factor prices will move in the future as they have in, say, the preceding decade. We shall make this assumption in the following comparisons.

Taking first the inventions and innovations, we find that the result of the introduction of the Houdry process was to substitute capital for fuel. In the ten years preceding Houdry's invention (1917-27), there was observable little change in relative factor prices of the two, both series fluctuating widely. The result of the introduction of the Fluid process was to substitute fuel for raw material for capital. Odell's invention of the fluidized bed was made in 1929; again no trend is evident in relative factor prices for the preceding decade. The substitution of one factor for another took place in spite of little change in relative factor prices.

Perhaps we would have better results if we took process improvements. During the period 1922-38 when the Tube and Tank and the other continuous thermal cracking processes were pre-eminent, the reduction in the consumption of the factors was greatest for fuel and less (about equally) for raw material and capital. Looking at movements of relative factor prices in the earlier period 1915-27 we find it difficult to generalize, although it does seem probable from the data that the price of fuel did not increase relative to the other two factors. During the period 1942-55, in the Fluid and other continuous catalytic cracking processes capital was being substituted for raw material for fuel. The trend of relative factor prices in the period 1932-45 was such that the price of fuel was rising relative to raw material. Based on substituting abundant for scarce resources, the predicted substitution would be raw material for fuel. In this case the prediction is correct. Because the trend in the relative price of capital differs depending upon which index we use, rising relative to fuel if rate of return is used as the measure of the price of capital, falling if construction cost is used, we cannot make any prediction as to the direction of substitution.

In conclusion, it may be possible in the case of process improvement to predict from earlier trends in relative factor prices the direction in which factor substitution will occur. In petroleum refining the data do not refute the hypothesis that improvement of techniques is 
achieved partially through the substitution of abundant for scarce resources. We are not justified, however, in extending this idea to radically new techniques, as changes in factor proportions necessitated by innovation bear little relationship to previous trends in relative factor prices. In process innovations it is probably the technological factors that are governing. 
